\title{
Competition criminal law: an international and global trend?
}

\author{
Inês Fernandes Godinho ${ }^{1, *}$, Nuno Castro Marques ${ }^{1}$ \\ ${ }^{1}$ Centro de Estudos Avançados em Direito Francisco Suárez (CEAD - Francisco Suárez), Lusófona \\ University of Porto, Faculty of Law and Political Science, Porto, Portugal
}

\begin{abstract}
.
Research background: Competition laws have become widespread and as a rule have a sanctioning nature. DANVERS refers an exponential increase in legal systems that introduced competition laws in recent years, accounting for more than 127 jurisdictions hereto. Specifically concerning the trend of criminalizing cartels, SHAFFER and NESBITT consider it due to transnational interests, and SÁNCHEZ defends a link between the economic subsystem as the engine of globalization and the economic law with the latter - where economic criminal law, competition law, financial markets law, among others are included - being subject to strong international influences, and possibly being moreover a sign of democracy. More than 30 jurisdictions already have criminalized cartels and STEPHAN mentions that about 60 jurisdictions already present internal legal solutions combining a reinforcement of sanctions with the figure of leniency, in a "carrot and stick" approach to destabilizing and deterring cartels.
\end{abstract}

Purpose of the article: Considering the cartel criminalization trend in competition law, it is paramount to identify the underlying legal interests as a (global) recognized fundamental value, even if there are particularities adjusted to each legal order, and the purpose of the article is to identify the legal interests and adscription criteria that may be considered and retained as common in competition enforcement.

Methods: normative analyses of the law.

Findings \& Value added: To discuss how to harmonize, in an international legal environment, competition enforcement.

Keywords: competition law; cartels; criminalization; harmonization

JEL Classification: $K 21 ; K 33 ; K 14$

\footnotetext{
* Corresponding author: ines.godinho@ulp.pt
} 


\section{Introduction}

Competition defence legal regimes typically prohibit agreements between undertakings that restrict or distort competition ${ }^{1}$. The term "agreement" covers both horizontal and vertical agreements, the first being concluded between undertakings that are, currently or potentially, at the same stage along the lines of the productive and / or distributive process. Among those horizontal agreements, those who involve price fixing and/or market sharing - known as cartels ${ }^{2}$ - are considered the most flagrant violation to competition. Indeed, it is only regarding cartel practices that a consensus exists as to its special reprehensibility and harm, justifying e.g. leniency programs despite moral reservations entailed by such programs [1]. The special gravity of cartel practices is internationally recognized ${ }^{3}$, being considered that cartels are highly detrimental to society or even "cancers on the open market economy" and "supreme evil of antitrust" [2], with "no legitimate purposes and serve only to rob consumers of the tangible blessings of competition" [3]. And it is towards such cartel practices that a global trend towards its criminalization can be identified and it is intended here to analyse that criminalization process from a perspective of its legal foundations not only in a competition law perspective but also in the light of standard criteria accepted in the field of criminal law.

\section{Methods}

In this paper, we analyse cartel criminalization trend through the method of normative analyses of the law in order to identify the underlying legal interests as a (global) recognized fundamental values and to assess if it may be considered and retained as common goals in competition enforcement.

\section{The origin of the globalization trend towards criminalization of cartels}

Competition defence is traditionally open to the interpenetration of international sources and solutions from different legal systems. But different national realities, due to distinct social, political and economic environments, pose the risk of endangering legal solutions when resulting from "legal transplants" without correct adaptation of the imported solution to the receiving legal system, in terms of legal tradition, culture, structuring principles and systemic congruence [4].

Legal systems have followed their own evolutionary paths and models of application of competition law are naturally conditioned by the existing institutional framework and its level of progress, with more developed and sophisticated regimes successfully achieving the transition to a model of criminal sanctions for competition infringements. But what is found is that there is not only a generalization of legal orders that introduced antitrust and

\footnotetext{
${ }^{1}$ As for European Union (EU), see art. 101 (1) TFEU.

${ }^{2}$ See the definition of cartel e.g. in art. 2 (14) of the Directive 2014/104/EU of the European Parliament and of the Council of 26 November 2014 on certain rules governing actions for damages under national law for infringements of the competition law provisions of the Member States and of the European Union (so-called Directive Private Enforcement).

${ }^{3}$ See the Recommendation of the Council concerning Effective Action against Hard Core Cartels. Paris: OCDE. (1998), where it is stated that "[...] hard core cartels are the most egregious violations of competition law [...]" (p. 2), or Defining Hard Core Cartel Conduct. ICN. (2005), considering an "[...] worldwide consensus [...] on the recognition that hard core cartels harm consumers and damage economies." (p. 5).
} 
competition defence systems, but also a trend towards the use of increasingly vigorous instruments for the detection of competition infringements, as well as for the an increasingly severe sanctioning practice. Such generalization of competition defence systems in national legal systems had a strong impulse from the "new" US effort to promote awareness of the international community in the fight against cartels. ${ }^{4}$ As Kovacic points out, since mid-70s of the 20th century that the persecution and punishment of cartels has been the "[...] core of antitrust enforcement in the United States [...]", and since mid90s an increasing number of other jurisdictions have also come to regard cartel detection and punishment as a priority.[5] Joshua et al. refer that since 1995 DoJ has put the fight against international cartels at the top of its priorities, considering that the change in attitude towards cartels globally is to some extent attributable to a robust US diplomacy that takes advantage of the absence of a world cartel enforcer.[6]

In addition to such "diplomacy", the US fight against cartels was reinforced with the introduction, in 1997, of the leniency regime alongside with a policy of effective application of criminal sanctions with effective prison sentences. And in the wake of the revision of the extradition mechanisms motivated by the post-9/11 reactions, the fight against cartels (included in white collar crimes) was also reinforced, with part of the extradition treaties being revised and moving from a previous "list" model (in which extradition was only possible for the crimes listed in each treaty) to a "double criminality" model (in which extradition becomes possible when the conduct is both a crime in the requesting and requested states), all putting pressure towards an increasing acceptance and openness to cartel' criminalization processes.

On the other hand, as important or more important than the sanctioning frameworks is the concrete application of the Law, and if in the early 70's there would already be the application of prison sentences, but only in about $8 \%$ of cartel cases sustained in court (or subject to "plea bargain"), with an average effective sentence served of 44 days; during the years of 2005-07 the average length of imprisonment for crimes prosecuted by the DoJ Antitrust Division was already 703 days, with imprisonment in $76 \%$ of the cases sustained in court [7]. In other words, the evolution of US competition law was based on an increase of the sanctions abstractly applicable and also, in particular from about 20 years ago to this part, in an increase of the sanctions concretely applied.

When considering Europe, EU clearly leads the way. Even if articles 101 and 102 of the Treaty on the Functioning of the European Union remain unchanged since the Treaty of Rome, the application of EU competition law has greatly evolved through secondary EU law and, above all, through an effective application by the European institutions, with an identical tendency to significantly increase the sanctions applied: after the 90 s of the last century, with a fairly reduced punitive activity, the trend was not only reversed but consistently showing an increase in the amount of sanctions imposed in cartel cases ${ }^{5}$. Even considering the lack of criminal competences of the EU, the fact is that there has always been a risk that the EU could apply extremely severe sanctions that can be equivalent or compared to criminal penalties, and since the Engel judgement ${ }^{6}$ European Court of Human Rights (ECoHR) established broad criteria for the interpretation and integration of situations in art. 6 of the European Convention on Human Rights (ECHR), establishing the content of minimum guarantees for a fair trial in criminal matters. In order to assess

\footnotetext{
${ }^{4}$ In the sense that the first US effort refers to post-World War II and its influence to the German competition law, that subsequently motivated German insistence for the introduction in the Treaty of Rome establishing the European Economic Community of the founding articles of the EU competition policy. From that point onwards, the dissemination of legal competition regimes through EU Member States was guaranteed.

${ }^{5}$ See the statistics in http://ec.europa.eu/competition/cartels/statistics/statistics.pdf.

${ }^{6} \mathrm{Judgement}$ of the ECoHR, Engel and others v. The Netherlands, of 8.06.1976.
} 
whether a certain procedure has a penal dimension, in the sense of the applicability of art. 6 of the ECHR, it is important to consider the classification of the infringement in domestic law, but only "a starting point", and the nature of the infringement, the nature and severity of the sanction, must also be considered, alongside in the risks incurred by the accused or defendant. $^{7}$ And in a more recent judgement in Menarini case ${ }^{8}$, in which a penalty of EUR 6 million imposed by the Italian competition authority on the company for participation in a cartel is analysed, the ECoHR considered that despite not being qualified under Italian law as a criminal offense, the same, considering its severity and repressive and preventive intention or deterrent, effectively possessed a criminal character and nature. ${ }^{9}$

MÖSCHEL clearly considers that exorbitant sanctions imposed for breach of European competition law "[...] have effects identical, or at least similar, to criminal sanctions. Any other perception would be a life lie." [8] Such a position is still controversial, and doctrinal divergence on the current situation of European competition law accommodates both the criticism for precisely having still a purely administrative nature when it would be appropriate to have already evolved to another nature, mainly criminal, and / or to preview other types of sanctions, such as sanctions for inhibiting companies condemned to participate in certain activities (e.g., in public tenders), or sanctions directed to managers (whether financial, management activity inhibition [9], or even criminal sanctions), and another position that considers that European competition law and its sanctions are of administrative nature and are (or remain) appropriate [10,11].

We consider unsustainable to consider the procedure and sanctions applied for breach of European competition law as simply administrative. The reasoning presented by the ECoHR in its judgements, the evolution of the mechanisms aimed at an effective and fortified application of European competition law, in addition to the escalation of the sanctions concretely applied, lead to a progressive understanding, in terms of jurisprudence and doctrine, of the sanctioning character of the European competition law. The awareness of societies has been fostered and promoted in order to attribute a high stigma to competition infringements, particularly cartels, with relevant reputational costs both for the companies involved and for their managers directly deriving from that stigma, together with a repressive or punitive tendency, accompanied by a strong deterrence public discourse justified by the need to guarantee protection of fundamental interests, clearly moves cartel infringements to a classic penal positioning.

EU is at a crossroads, as it does not have criminal powers or competences. But without such a limitation, it is a straightforward conclusion why some Member States have been gradually evolving, in their national competition laws, towards criminal or quasi-criminal solutions: they are indeed more appropriate, adequate, proportional and fair when it comes to apply the procedures and sanctions previewed to competition infringements.

\section{The grounds generally invoked for the criminalization of cartels}

In the pro and cons regarding criminalization of cartels [12], a common core of favourable arguments can be identified, based on the negative impact of cartels on economic and consumer welfare; similarity of cartels to crimes against property [13] or even to crimes in which the element of breach of trust is highlighted; moral wrongness of the conduct, sometimes presented as similar to theft, fraud, insider trading, market manipulation and other "white collar" crimes and, considering such similarities, being necessary to provide

\footnotetext{
${ }^{7}$ See $\S 82$ and 83 of the judgement.

${ }^{8}$ Judgement of the ECoHR, Menarini Diagnostics s.r.l. v. Itália, of 27.09.2011.

${ }^{9}$ See $\S 38$ to 44 of the judgement.
} 
comparable sanctions and remove the perception that perpetrators of "white collar" crimes would be treated more benevolently compared to perpetrators of common crimes [14]; its secrecy and conspiracy character, with inherent difficulty of detection and punishment, associated with an insufficient deterrent effect resulting from financial penalties, where its optimal level would need to be so high that would pose a serious risk of bankruptcy for the undertakings involved. Such risk would inevitably be transmitted to "innocent" parties, such as workers, partners or creditors of the sanctioned undertakings, as opposed to the possibility of deprivation of liberty to individuals with direct participation in the cartel - in an argumentation also aligned in terms of corporate governance due to the individual incentives of managers to engage in cartels [15].

Notwithstanding the accuracy of these arguments, we do not consider them sufficient to sustain the fundamental option of criminalization, or not, of cartel practices. In fact, part of the arguments relate to the appreciation of behaviour and as CASTILLO DE LA TORRE rightly stresses, the legal interest to be protected by the norm should not necessarily be confused with the conduct that is prohibited [16]. On the other hand, it is hard to identify global legal interests within the scope of economic law. In fact, the existence of any global legal protected interest under economic law is doubtful and economic criminal law has never been an instrument to drive the economy, much less will it be a useful tool to drive or transform the world economy. [17, 18]

SHAFFER and NESBITT refer to the transnational relevance attributed to cartel prosecution and consider that criminalization processes seem to be more due to transnational interests than to "[...] domestic bottom-up processes." [19] But this comes up against the characteristic that economic criminal law is of a markedly national nature, which perhaps justifies one of the difficulties pointed out to the criminalization of cartels and precisely relating to the need for a correct balance between a legislative will to increase deterrence and an effective application of the Law, as when "[...t]he scarcity of public criminal enforcement record raises concerns [...] therefore, the marginal deterrence is close to zero accordingly." [20] The risk of a weak enforcement of the law considerably increases if the criminalization process is based only on transnational movements of legal transplants and not, as it should, based on axiological foundations recognized by the legal order. Also, a failure to ensure proportionate overall punishment is possible due to weak coordination [21].

We should then move on to another level of discussion, regarding the very essence and raison d'etre of the object of protection of the norm, that is, the legal interest. Competition defence is multivalued but even that produces a clear positive aspect as it shall be considered as one of its legal, economic and social robustness.

A preliminary note is that it seems clear to us that some of the economic fundamentals attributed to competition do not seem to meet the characteristics of density, dignity, axiological valuation and ethical-social justification necessary to be considered as a legal interest that should benefit from a normative protection (specially with criminal nature). Protection of economic efficiency (or allocative, productive, and / or innovation efficiency), or the welfare of the consumer (in abstract terms) or even the total welfare do not justify the prevision of last ratio sanctions such as imprisonment. Therefore, values of higher relevance will certainly be present, justifying also the dissemination of such a maximum degree of normative protection (criminal) in an increasingly number of legal orders.

However, in a criminalization process the concept of protected legal interest is central. [22] But the fact is that a legal interest does not mean ipse iure that is eligible to be considered as legal-criminal interest. It will only be so if it passes the cumulative criteria of criminal dignity, need for "criminal" protection, and the subsidiary nature of this nature of protection as an ultima ratio. It will then be necessary to identify the fundamental 
objectives normally attributed to the defence of competition and, subsequently, try to fit them into legal interests with criminal dignity in the context of economic criminal law.

As for "political" objectives, competition defence is always based in one or more of the following: control of economic power; safeguarding the freedom of individuals and business; redistribution; and / or consumer protection, and as for economic objectives we find the "Smithian" rivalry as the first structured basis of a competition concept (competitive process) between economic agents and expecting that through a rivalry process where economic agents have freedom to act the result will be a constant increase in efficiency and welfare maximization. To those typical competition objectives, also typical economic criminal law objectives should be added, such as the protection of property as well as the values of transparency and trust as a mutual recognized value.[23]

It is then possible to proceed to a confluence between competition objectives and legal interests traditionally protected by economic criminal law, being adequate to be considered as legal interests to be protected through a process of cartel criminalization the values/legal interests of economic power control, freedom of individuals and companies defence (freedom of action, decision, market access and of choice), consumer protection, and protection of trust, transparency and property.

\section{Results of the appraisal of legal interests protected by competition law and evaluation of cartels against other competition infringements}

The analysis can be complemented by identifying the legal interests infringed by cartels (and "bid rigging"), and corresponding intensities, in contrast to the abuse of a dominant position - the other major competition law infraction - so to further deepen the basis for the criminalization process that generally focus only on cartels. Despite the consensus qualifying cartels as the most serious conduct in the context of competition infringements, a more dense analysis for such differentiation can and should be added.

A cartel is a relevant example of the possibility of a direct and intense attack on the control of economic power value. Likewise, a cartel in a public tender constitutes a serious and intense violation of the subordination of private economic power to societal objectives since e.g. a cartel resulting in public services acquisitions at supra competitive prices produce a damage that correspond to amount of public resources that are no longer available for allocation to other needs or public policies. An abuse of a dominant position also has the potential to seriously and intensely violate the value of controlling economic power. But in its most extreme form, including all the relevant producers of a given good or service in a given geographic market, a cartel has the potential to empower each of its members with the power of a monopolist.

As for the legal interest of protection of the freedom of individuals and business, it is equally easy to foresee that a cartel has all the characteristics for a serious infringement. Considering the protection of rivalry (competitive process), of the market structure (competitive structure), of the freedom of individuals and business, and of the efficiency and welfare maximization, a cartel represents all the contrary to what is intended to be protected. A cartel is the denial of the competitive process, with its members eliminating, by collusion, competitive tension and risk, as well as mutual rivalry. The members of a cartel substitute the risks of competition by coordination of commercial strategies and actions in the market, so under the guise of diversity from a variety of economic agents, the offer of a good or service obeys, secretly and illicitly, to a single strategy. That is why the cartel is also in violation of the competitive structure of the market, since what is expected is that a structure composed of several agents produces a competitive process, with rivalry 
and the expected benefits deriving from it. When through a cartel, such agents eliminate rivalry, they distort the market structure and tampering it from its competitive characteristics and bringing it closer to another type of structure that, at its extreme form, can resemble - but with the aggravation that without consumers knowing it - to a monopoly structure. The negative impact of a cartel on the differentiation by innovation is also remarkable, since having agreed on their commercial strategies, namely by fixing prices, market shares or customer allocation, any of these agents will no longer feel pressure or need to innovate or to differentiate themselves from the rest of the "competitors".

Consequently, a cartel favours or even, in extreme cases, enables the crystallization of its members' positions in the market, giving them the power to access benefits they would not otherwise obtain: by being able to charge a collusive and supra-competitive price, cartel members obtain a patrimonial benefit; by acquiring or retaining customers as a result of customers or markets allocations, they obtain a patrimonial benefit; by maintaining their relative market shares, as a result of a quota agreements and again without having to expend efforts to do so, they obtain a patrimonial benefit; by maintaining, as a result of collusion, their market positions without needing to invest or improve services or products, they obtain a patrimonial benefit. All these patrimonial benefits correspond to a loss of economic efficiency in any of its possible meanings, either due to a transfer of resources to cartel members that would not otherwise be necessary, or to the fact that supra-competitive prices mean that cartel members are in fact allowed to produce their products or services at inefficient levels but without suffering the market consequences that would normally be expected in short or long-term, or either by enabling low innovation performance of the services or products offered by cartel members. As such, a cartel constitutes a violent attack on efficiency and welfare maximization. It also directly infringes multiple essential aspects of the individual's freedom, as among other collusive aspects it may have elements of reaction and elimination of other or new competitors, that being an example of an illegitimate attack on the freedom of economic initiative, dishonestly preventing other citizens to act in the economic field, to access markets or even in some cases to exercise the fundamental freedom to choose a profession. Moreover, a cartel that entails an absence of differentiation in prices or products, or even client sharing, distorts the freedom of action, of decision and prevents the freedom of choice of those affected.

It may properly be considered that an abuse of a dominant position has a similar capacity to infringe the legal interest protecting individual and business freedom. The cartel can do it with even greater damage and intensity and, above all, in a secret, covert and subversive way. That is, with an element of "cheating", "subvert competition", "subvert a competitive market" and "subvert the competitive process".

Consumer protection is another legal interest that the cartel infringes. Cartels usually involve price fixing, market division, limitation of technological improvement and or of production as competition presents a causal link with innovation [24]. When consumers are obliged to pay a cartelized price, surely their economic interests are not being respected. And when they are prevented from accessing differentiated, improved or innovative products, as a result of collusion, their rights to the quality of goods are also being disrespected. The quality of the goods they can choose is the one, and only the one, that cartel members decided consumers could choose.

This same argument is applicable in the case of abuse of dominance, as consumers will bear the price, availability and quality of products that the monopoly or quasi-monopoly producer has decided. But, and again, we see a difference: the consumer will normally realize that he is facing a dominant company, being able to react with the extreme and perhaps unique decision that still remains (but not considering here the damage or inconvenience that may result from it), that is to decide not to consume. Already opening a path for the consideration of the value of trust as a legal interest to be protected, in the case 
of the cartel consumers do not have such a prior perception and (wrongly) believe that they are interacting with one of several agents existing in the product market and, thus, being able to opt and choose. In fact, it seems to us that anyone who interacts with a dominant company will not have the same degree of confidence in the balance of the relationship as when interacting with a company believed to be in a competitive process with other companies in the same market. In other words, the competitive structure is already weakened due to the presence of a dominant company, so that it will be perceived by consumers that this dominant company is expected to be less sensitive to the consumer sovereignty. Therefore, the confidence placed in their "dominant" counterpart will be much less - or perhaps none - when compared to the one they place when for a given product or service consumers have a diversity of offers and choice and look and decide upon such different offers. Trusting those offers are produced in a competitive structure capable of generating competitive processes based on rivalry, the customers of cartel members normally only perceive that they have been cheated when the cartel is detected and made public. Until then, costumers intervene in the commercial relations assuming that they are interacting with companies who decide autonomously their market behaviours.

It is also for this reason that the cartel represents an intense attack on transparency, due to its secretive and conspiracy characters with the purpose of deceiving the public. The abuse of a dominant position is also distinctive from the cartel regarding transparency, as it is a unilateral (and objectionable) behaviour, but not covered with this conspiracy and secrecy aspects. On the contrary, it is from the conduct revealed in the market that it will be possible to suspect or detect whether the dominant company is engaging in an (exploitative or exclusionary) abusive strategy, not hiding its behaviours. It will normally not reveal its reasons and intentions, but, unlike the cartel, dominant form will nor act with secrecy over its customers.

Breach of the property value is also particularly relevant in case of cartels. Although the recognized difficulty to quantify damages resulting from a cartel, there is nevertheless the certainty of its high aptitude to produce property damage, and to only to costumers [25]. In this regard, the Competition Committee of OECD concluded that "[...] the cartel mark-up can vary significantly across cases, but in some it can be very large, as much as $50 \%$ or more. Thus, it is clear that the magnitude of harm from cartels is many billions of dollars annually." 10 An abuse of a dominant position may also cause substantial damage to property. Like a cartel, a dominant company may, for example, charge supra-competitive prices or exclude competitors from the market. But the fact of the matter is that the Directive "Private Enforcement" established an iuris tantum presumption of harm causation relating to cartels - art. 17(2). Being the Directive's purpose the harmonization of certain rules governing actions for damages for breaches of competition law (arts. 101 and 102 TFEU), the fact is that it established such a presumption only for cartels, thus recognizing its distinctive characteristic also relating to harm to the property legal interest.

In short, notwithstanding the fact that it is very difficult to point out a specific protected legal interest with regard to the criminalisation of cartels, it is also true that a criminal offence can have a polyhedric protected legal interest. In the case of cartels, several relevant protected legal interests can be identified as to their dignity and correlative need for criminalisation, with respect for the ultima ratio principle.

This is why one can clearly observe such a strong trend in the criminalisation of cartels; nonetheless, the offences continue being tailored according to local legal orders, since criminal law is mainly local. The interesting future question is if cartel criminalisation will find a common ground to constituting part of an international "catalogue" of crimes -

${ }^{10}$ Fighting Hard-core Cartels: Harm, Effective Sanctions and Leniency Programmes. Paris: OCDE. (2002), p. 72. 
considering its international relevance and global impact - or if it will remain a global fight with local battles.

\section{Conclusions}

Prohibition and sanctioning of cartels (and bid-rigging) may be based on the protection of legal interests typical to economic criminal law. In this sense, cartel criminalization should be based not only in grounds deriving from the competition field, but also and substantively by usage of the classic framework and methodology of criminal law, i.e. clear identification of the legal-criminal interest(s) to be protected and recognition of its criminal dignity, need for criminal protection and its adequacy considering the subsidiary nature (ultima ratio) of criminal law.

On the other hand, the justification of the cartels' distinctive characteristics in relation to other competition infringements must also be carried out using the classic instruments of criminal law. And at this respect it can be concluded that cartels indeed present distinctive characteristics placing them at a level of seriousness and damage higher than other competition infringements - namely the abuse of a dominant position -, and moreover constitute the conduct that simultaneously infringe all the potential legal interests protected by competition law and always doing it with a high degree of intensity.

\section{References}

1. Blum, U., Steinat, N., Veltins, M. (2009). On the rationale of leniency programs: a game-theoretical analysis. European Journal of Law and Economics, 25(3), 209-229.

2. Harding, C. (2011). Cartel deterrence: The search for evidence and argument. The Antitrust Bulletin, 56(2), 345.

3. Werden, G. J., Hammond, S. D., Barnett, B. A. (2011). Deterrence and detection of cartels: Using all the tools and sanctions. The Antitrust Bulletin, 56(2), 207-234.

4. Kunzlik, P. F. (2003). Globalization and hybridization in antitrust enforcement: European "borrowings" from the US approach. The Antitrust Bulletin, Summer, 319353.

5. Kovacic, W. E. (2006). An integrated competition policy to deter and defeat cartels. The Antitrust Bulletin, 51(4), 813.

6. Josua, J. M., Camesasca, P. D., Jung, Y. (2008). Extradition and Mutual Legal Assistance Treaties: Cartel Enforcement's Global Reach. Antitrust Law Journal, 75(2), 353-397.

7. Werden, G. J. (2009). Sanctioning Cartel Activity: Let the Punishment Fit the Crime. European Competition Journal, 5(1), 19-36.

8. Moschel, W. (2011). Sanctioning Cartel Activity: Let the Punishment Fit the Crime. European Competition Law Review, 32(7).

9. Khan, A. (2012). Rethinking Sanctions for Breaching EU Competition Law: Is Director Disqualification the Answer? World Competition, 35(1), 77-102.

10. Billiet, P. (2009). How lenient is the EC leniency policy? A matter of certainty and predictability. European Competition Law Review, 30(1), 14-21.

11. Handrlica, J. (2020). Is There an EU International Administrative Law? A Juristic Delusion Revisited. European Journal of Legal Studies.

12. Stephan, A. (2017). An empirical evaluation of the normative justifications for cartel criminalisation. Legal Studies, 37(4), 621-646. 
13. Beaton-Wells, C., Parker, C. (2013). Justifying criminal sanctions for cartel conduct: a hard case. Journal of Antitrust Enforcement, 1(1), 198-219.

14. Connor, J. M. (2011). Problems with prison in international cartel cases. The Antitrust Bulletin, 56(2), 311.

15. Monnier, C., Combe, E. (2020). Why Managers Engage in Price Fixing? An Analytical Framework. World Competition, 43(1), 35-60.

16. Castilo de la Torre, F. (2009). Evidence, Proof and Judicial Review in Cartel Cases. World Competition, 32(4), 505-578.

17. Feijoo Sánchez, B. (2012). Transformación del derecho penal por la protección de la estabilidad financiera internacional como bien jurídico global? Anuario de la Facultad de Derecho de la Universidad Autónoma de Madrid, 16, 109-136.

18. Witt, M. A. (2019). De-globalization: Theories, predictions, and opportunities for international business research. Journal of International Business Studies, 50(7), 10531077.

19. Shaffer, G. C., Nesbitt, N. H. (2011). Criminalizing Cartels: A Global Trend? Legal Studies Research Paper Series.

20. Brisimi, V., Ioannidou, M. (2011). Ciminalirzing Cartels in Greece: A Tale of Hasty Developments and Shaky Grounds. World Competition, 34(1), 157-176.

21. Huizing, P. J. F. (2020). Proportionality of Fines in the Context of Global Cartel Enforcement. World Competition, 43(1), 61-86.

22. Godinho, I. F. (2017). The criminal offence - definitions and internal structure in Portugal. In U. Sieber, K. Jarvers, \& E. Silverman (Eds.), National Criminal Law in a Comparative Legal Context (pp. 50-58). Berlin: Duncker \& Humblot.

23. Willems, A. (2016). Mutual Trust as a Term of Art in EU Criminal Law: Revealing its Hybrid Character. European Journal of Legal Studies, 9(1), 210-249.

24. Aghion, P., Bechtold, S., Cassar, L., Herz, H. (2018). The Causal Effects of Competition on Innovation: Experimental Evidence. The Journal of Law, Economics, and Organization, 34(2), 162-195.

25. Bueren, E., Smuda, F. (2018). Suppliers to a sellers' cartel and the boundaries of the right to damages in U.S. versus EU competition law. European Journal of Law and Economics, 45(3), 397-437. 